ulation: analysis of reports to the Danish Medicines Agency over a decade. BMC Res Notes 2010;3: 176.

3. Savolainen H. Differentiation of human cortical neurons: proteins of subcellular particles. Comp Biochem Physiol B 1973;44:467-472.

CMAJ 2011. DOI:10.1503/cmaj.111-2055

\section{Concussion in youth hockey}

In his article on concussion in youth hockey," Johnson writes that "Crosby has a lot of company in the NHL [National Hockey League], where the number of concussions doubled in the 2010/11 season," "citing a reference to www.nhl.com. ${ }^{2}$ This is in error.

The cited article does not say that. In fact, NHL Commissioner Gary Bettman is reported to have handled the question of number of concussions this season as follows: "Bettman declined to reveal any numbers regarding the number of concussions sustained this season or what percentage they have risen to." $" 2$

Another NHL release reports: "Accidental concussions have nearly doubled this season from last season. In 2010 11, NHL Hockey Operations has determined that $26 \%$ percent of the League's reported concussions were the result of accidents. According to the terms of the study, accidental concussions involve a hit from a teammate, a trip or fall (not caused by an opponent), being struck by a puck or an inadvertent collision with an opponent." ${ }^{\prime 3}$ The NHL has reported that $26 \%$ of concussions for this season are accidental, $44 \%$ legal, $17 \%$ illegal, and $8 \%$ fight-related; the remaining 5\% are undefined because no videos of the incidents exist. ${ }^{4}$

Johnson appears to be confused by this breakdown and the reporting of concussions by the NHL. I can find no report of the actual number of concussions for the 2010-2011 NHL season. I ask why "Bettman declined to reveal any numbers regarding the number of concussions sustained this season."

\section{David Rhine MD}

Department of Emergency Medicine, Kelowna General Hospital; clinical instructor, Department of Emergency Medicine, University of British Columbia, Kelowna, BC

\section{References}

1. Johnson LSM. Concussion in youth ice hockey: It's time to break the cycle. CMAJ 2011;183:921-4.

2. Associated Press. NHL concussions on rise, accidental hits blamed. 2011 Jan. 29. Available: www.nhl.com/ice/news.htm?id=551016 (accessed 2011 May 25).

3. Associated Press. Study: time lost from illegal hits are down. 2011 Mar. 14. Available: www.nhl.com /ice/news.htm?id=555980 (accessed 2011 May 25).

4. Associated Press. Bettman discusses concussions, player safety. 2011 Mar. 14. Available: www.nhl .com/ice/news.htm?id=556046 $($ accessed 2011 May 25).

CMAJ 2011. DOI:10.1503/cmaj.111-2052

I believe the issue raised by Dr. Rhine would benefit from some clarification.

Although the NHL declines to release figures on the number of concussions, it acknowledges that concussions are "on the rise" in the 20102011 season. ${ }^{1}$ The league attributes the increase to accidental hits, which account for $26 \%$ of concussions. ${ }^{2}$ The number of concussions attributed to accidental hits in the 2010-2011 season nearly doubled from the previous season. ${ }^{2}$ Legal hits account for $44 \%$ of reported concussions in the 2010-2011 season. ${ }^{2}$

\section{Syd M. Johnson MA PhD}

Novel Tech Ethics, Dalhousie University, Halifax, NS

\section{References}

1. Associated Press. NHL concussions on rise, accidental hits blamed. 2011 Jan. 29. Available: www .nhl.com/ice/news.htm?id=551016 (accessed 2011 May 25).

2. Associated Press. Study: time lost from illegal hits are down. 2011 Mar. 14. Available: www.nhl .com/ice/news.htm?id=555980 $($ accessed 2011 May 25).

CMAJ 2011. DOI:10.1503/cmaj.111-2053

\section{Letters to the editor}

In submitting a letter, you automatically consent to have it appear online and/or in print. All letters accepted for print will be edited by $C M A J$ for space and style. Most references and multiple authors' names and full affiliations will appear online only. (The full version of any letter accepted for print will be posted at cmaj.ca.) 